\section{B A Institute of \\ Yk Business Administration \\ 光 \\ Karachi \\ Leadership and Ideas for Tomorrow}

\section{Business Review}

Volume 2 Issue 1 January - June 2007

$1-1-2007$

\title{
The analysis of non-financial qualitative factors for corporate value creation
}

Syed Umar Farooq

Allama Iqbal Open University, Islamabad, Pakistan

Follow this and additional works at: https://ir.iba.edu.pk/businessreview

Part of the Business Commons

(c) (i)

This work is licensed under a Creative Commons Attribution 4.0 International License.

\section{Recommended Citation}

Farooq, S. U. (2007). The analysis of non-financial qualitative factors for corporate value creation. Business Review, 2(1), 161-167. Retrieved from https://doi.org/10.54784/1990-6587.1118

This article is brought to you by iRepository for open access under the Creative Commons Attribution 4.0 License and is available at https://ir.iba.edu.pk/businessreview/vol2/iss1/11. For more information, please contact irepository@iba.edu.pk. 


\title{
DISCUSSION
}

\section{The Analysis of Non-Financial Qualitative Factors for Corporate Value Creation}

\author{
Syed Umar Farooq \\ Allama Iqbal Open University, Islamabad, Pakistan
}

\begin{abstract}
Interviews conducted with the major KSE (Karachi Stock Exchange) Fund Managers revealed that they all faced problem of ignorance and uncertainty in stock selection and in asset allocation decision. The problems were due, in part, to the limitations of finance theory and the limitations of corporate disclosures and other public domain information sources. These problems increased fund manager's incentives to directly contact senior management teams to discuss these sources of value and to observe management qualities and understanding of these issues. Fund managers sought to identify links between these qualitative factors in a corporate value creation process. This paper explores how this information was used by fund managers to acquire a knowledge advantage. This activity of fund managers has important implications for regulatory policy issues on insider information, on corporate disclosure, on the corporate governance role of financial institutions, and for the governance of the institutions.
\end{abstract}

\section{INTRODUCTION}

T $\mathrm{n}$ section 1, we explore how major KSE fund managers faced problems in stock 1 selection and in asset allocation decision. Than we will see how fund manager directly contacted senior management teams to discuss concrete and intangible sources of value. We explore how the fund managers identified the many qualitative components of the corporate value creation process.

\section{Research Method}

Interviews were conducted with 20 Fund Managers during the period of January 2005 and April 2006. Each fund manager case participant had the interview questions for at least a month before the interview.

The interview case data revealed many different themes concerning financial institution information collection from their investor companies and significance for fund management. These themes have been identified through a Glaser and Strauss (1967) 'grounded theory', approach to the case data. The interview case data formed the basis for identifying common patterns and themes across the cases. Generalizations have been restricted to the cases studied. 


\section{Public information sources for fund managers: Company and sector level}

In this section, we explore how the case fund managers faced problems of ignorance and uncertainty in stock selection and in asset allocation decisions. These problems were due, in part, to the limitations of corporate disclosures and of other public domain information sources. Associated problems also arose for the case fund managers because of major difficulties in implementing modern portfolio and aspects of finance theory in fund management decision. These problems with public information sources and with the conceptual framework for fund management were a major stimulus for creating structured fund management decision processes to cope with uncertainty and ignorance and a strong incentive to acquire private information directly from companies.

Public sources of information included company announcements and financial results as well as government announcements. Major sources of fund managers' information were the brokers through which the fund managers bought and sold shares. The main broker houses were Taurus Securities, KASB Securities, Invest Cap, Saleem Chamdia Securities and First National Equities. Fund managers faced a major problem in that all of the major information and data suppliers provided historic, mainly public domain information. They also provided software to analyze this data and establish summary statistics. The fundamental problem with these public sources was that the information was perceived as already being in the price, with the price change not necessarily indicating the nature of the event or information.

The case fund managers argued that they needed a special information edge for fund management roles and this was unlikely to be found with financial reports, public announcements, public domain analyst reports on companies and other public sources. As a result, the limitations of public sources provided the fund managers with strong incentives to develop private corporate sources of information. However, despite the limitations of public sources of information, they play a central role in fund management because they form the primary sources of financial and quantitative information about corporate performance and focus on well established financial output measures. Stopford (1997) argues that the fusion of the information age with traditional industries has been a primary driver of innovation. This has increased the ability of companies to change the rules of competition and the chances of corporate failure. As intangibles such as knowledge and innovation have become an increasingly important part of corporate value then this has exacerbated to the problem of how to disclose the value of these assets on the balance sheet and how to explain the manner in which profits arise from such intangibles. These problems of financial reporting of intangibles have increased the information asymmetry between users and suppliers of equity risk capital.

\section{PROBLEM OF IMPLEMENTING FINANCE THEORY}

The case fund managers faced major problems in implementing finance theory, especially with the CAPM when estimating stock returns and when using optimization routines to find the efficient frontier and the optimum risk, return portfolio. The problems arose, in part, because of the limitations of public domain data and because 
of the uncertainty implicit in forecasting stock risk and return characteristics. These problems also arose because of the main controversies and fundamental problems facing finance theorists. Markowitz (1952) laid the foundations of modern portfolio theory. He stated that investors seek a risk/return trade off by seeking to maximize returns for a given level of risk or to minimize risk for a given level of return. This information could be used to generate a large number of feasible portfolios which were dominated by a smaller number of efficient risk/return portfolios lying on the efficient frontier.

Risk averse rational portfolio managers could choose one of the portfolios to reflect their or their clients' risk/return preferences (utility). Given the input data, the portfolio selection problem could be solved to find the optimal solution using a quadratic programming approach. This approach was further simplified by the development of the CAMP by Sharpe and Lintner in the 1960's. They identified a single factor, linear model, with which a company's Beta measured the stock's return volatility relative to that of the overall market. Markowitz further argued that finance theory tells us what is to be estimated in the form of future risk and return and how estimates for specific shares are to be combined to form estimates for the portfolios as a whole. However, theory does not tell us how to make the estimates of return, variance and covariance. Markowitz pointed out the controversy regarding which measure of risk to employ. In particular there has been a major academic dispute in the empirical validity of the CAPM and of betas in determining security returns and prices.

Given these theoretical difficulties, none of the case fund managers felt they could construct a portfolio with the ideal risk/return tradeoff and diversification risk benefits envisaged by theory. Finding a stable efficient frontier was problematic in this context. Despite these problems with modern portfolio theory, the existing theory provided the sole conceptual guide for fund managers in their difficult asset allocation and stock selection decisions.

\section{VARIETY IN THE FUND MANAGER'S SAMPLE}

One conclusion we can derive from this is that whilst theorists and empiricists continue to improve theoretical framework, the best practitioners can do is to recognize these theory limitations and to draw on the best insights of theory to guide their decisions. The case fund managers divided in terms of quantitative (strong use of quantitative (QM) aspects of theory) versus qualitative preferences. Major factors here were fund managers' judgments as to the credibility of the numbers used in the QM approach, the weight of evidence for and against theoretical approaches, as well as personal decision style preferences.

For the quantitative case fund managers (16 FM's), public domain information on share prices provided the means to calculate historic average returns, variance, covariance and market weightings. Public domain sources such as financial reports, corporate disclosure and future looking data such as analysts' earning forecasts were important means to adapt these historic figures to estimate future returns, variances, covariance and weightings. 
In qualitative fund management (24 FM's) the view was taken that modern finance theory was too difficult to implement given information problems and time constraints. Portfolio theory and diversification benefits were accepted but constrained asset allocation optimization techniques were not. Public domain information on sectors and major companies were combined with macro economic forecasts to arrive at asset allocation decision within a more judgmental and intuitive collective decision process. These fund managers also recognized that their judgmental skills were unlikely to produce above average performance on the basis of public domain information alone.

\section{INTELLECTUAL CAPITAL AND THE UNIQUE PRIVATE AGENDA}

The unique private information agenda consisted of, in part, a very different information agenda as compared to that employed for the public channels. A key part of private agenda was a dialogue about public information sources, especially quantitative financial information sources such as the financial report. In contrast, the unique private agenda included information on qualitative, non financial company variables such as quality of management, strategy and its coherence, investment and financing plans, recent changes in these and in corporate succession and management style. Information on competitors and the structure of competition was very important. Other information sources here included a supportive company climate for innovation and long term investment in productive and human assets, R\&D; Expenditure, flexibility of company to technological change and the role of internal financial resources.

They also used ideas of human capital such as management's track record in dealing with risk over time as an important source of information on risk management capabilities. Both forms of structural and human capital revealed much about corporate attitude to risk, as well as corporate responsiveness to financial and business risk and hence corporate vulnerability. The case fund managers ensured against high risk management teams by preferring to invest in companies that adapted to good financial risk management practices. They preferred good financial risk practice companies because they perceived that the information asymmetry they faced in company financial risk and risk management was extensive.

The regular interaction of the case fund managers with various portfolio companies shows that the fund managers were in a unique position to learn how elements of structural capital, such as strategy and board structure, the character of innovation and various management practices, all interacted with elements of human capital such as management quality, to contribute to good financial performance in different ways across diverse companies and industries. They could also observe the collective effect of these variables on financial performance and share prices. This provided the means for fund managers to develop a knowledge advantage concerning these qualitative factors and variables in the corporate value creation process.

Once the case fund managers acquired knowledge advantage concerning the corporate value creation process, they were in a position to analyze macro and competitive changes in the company's environment and to assess their effect on the company and 
the likely corporate response. This in turn provided the means to estimate corporate returns, their risk vulnerability and corporate value. In order to determine if the fund managers have an information advantage, the case fund managers argued that, if they had secured unique information, their company valuation was likely to be superior to that prevailing in the market place. This belief was not necessarily based on some idea of market inefficiency.

Fund managers did not believe that the market was full form or strong form efficient. Rather, they argued that the information gap between semi strong and strong form was significant and that this gap provided a major incentive for a huge and active market for information. They therefore tried to gain two advantages. The first was to gain access to private company information. The second was to develop unique skills in processing both private and public sources of information. Keane (Stock Market Efficiency, 1983) refers to these as information and processing advantages.

Relationship sources of information were likely to be somewhat different in publicly available sources of data. They provided information that was more timely and close to the return and risk generating process than the current public domain data. They also provided novel insights into many intangibles concerning corporate risk, including management attitude to risk, and management capability to risk management. Additionally, they provided new information on risk that was not generally available. The private information appeared to be different in character to publicly available information in that it emphasized qualitative, difficult to observer aspects of the risk and return generating process and the risk management process. This included information on intellectual capital factors such as the qualities of the management team, their understanding of strategy, their impact on the risk and returns generating process, their attitudes to risk and track record in handling risk.

\section{USE OF PRIVATE INFORMATION IN TOP-DOWN AND BOTTOM-UP RISK CONTROL}

The private insight into the risk, risk management and risk attitudes was used to manage risk in a bottom up manner as well as top down manner expounded by conventional portfolio theory. More specifically, fund managers used direct contact with relationship companies to identify high risk, low return companies and to drop them out of their portfolios. In the majority of fund managers' cases, mean-variance and optimization approaches were either not employed or were only used as a supplementary source of information at the top down level. The majority of these qualitative fund managers argued that at various times, they found themselves either too information constrained, or too ignorant, to find robust and stable optimal portfolio solutions for the future concerns. A small number of them also argued that experience and intuition alone were much better guides than these quantitative models. 


\section{CONCLUSIONS}

This paper has explored how fund managers deal with major problems of ignorance and uncertainty in stock selection and in asset allocation decisions. These problems arose due to the limitations of public domain information sources, but they were exacerbated by an increasing intellectual capital and intangible components to share prices. As a result, the case fund managers used private meeting with company management to understand how value arose through intangibles as well as through tangible assets. The case data revealed the nature of this private information agenda concerning intellectual capital or intangibles and the dynamic connections between these variables in the value creation process. This private information was combined with public sources to create a knowledge advantage within case fund management teams. It was found that the learning and knowledge advantages played a central role in framing fund managers' perceptions of corporate gains, losses and risks. The knowledge advantage and prior framing were used by fund managers to estimate future corporate performance variables to evaluate the company. The case data thus provided some insight into how the book value and market value gap arose and the special role of information on intangibles and intellectual capital in valuing the company. Private information, the knowledge advantage and prior framing were also key inputs to bottom up and top down portfolio risk control and asset allocation by fund managers. The private information sources were used to remove the poor performance from the portfolio. In addition, they were used to understand which companies and sectors were likely to be winners and losers under forecast macro conditions. Both bottom up and top down risk controls were expected to boost fund performance. This fund management behavior has important implications for regulatory policy issues on insider information, the corporate disclosure, the corporate governance role of financial institutions and for the governance of financial institutions. In the case of insider information, the fund managers were clearly acquiring an inside knowledge advantage through their regular direct contact with companies.

Finally, we need to ask the following questions. Should the market information benefits arising from fund manager being informed in this private way about intangibles, be restricted in the interest of fairness to small investors in financial markets? Secondly, can the private disclosure process offer ideas on how to improve the public disclosure process? Thirdly, should the informed fund managers be asked to pursue wider governance aims in the interests of many savers, stakeholders and the public at large? Finally, in connection with the larger issue of governance, we must talk: who governs the directors? These questions are likely to become more urgent in the knowledge decades ahead as the information asymmetry based on intangibles becomes acute and an increasingly concentrated and global fund management industry continues to exploit knowledge and power in the interest of favored groups of savers and shareholders.

\section{REFERENCES}

Arthur, A., 'Accounting and Standards Board', Central Milton Keynes, ASB Publications, 1998. 
Barker, R. 'The role of dividends in valuation models used by analysts and fund managers', University Cambridge Working Paper, 1998.

Biddle, G.C., Bowen, R.M., and Wallace, J.S. 'Evidence on EVA', Journal of Applied Corporate Finance, 1999.

French, K.R., and Poterba, J.M. (1991). 'Investor Diversification and International Equity Markets’, American Economic Review 81: pp. 222-226.

Kaplanis E., and Schaefer, S. 'Exchange risk and international diversification in bond and equity portfolios', Journal of Economics and Business, 1991.

Lang, M.H., and Lundholm, R.J. 'Corporate Disclosure policy and Analyst behavior', The Accounting Review, Vol. 71, No. 4, October 1996, pp. 467-492.

Sharpe, W.F., Alexander, G.J., and Bailey, J.V. (1995). 'Investment', Prentice Hall.

Smith, M.P. (1997). 'Shareholder Activism by Institutional Investors, Evidence from Calpers', Journal of Finance, Vol. 51, No. 1, pp. 227-252,1996.

Stopford, J. Global Strategies for the Information Age', Prentice Hall, 1997.

Weetman, P., Collins, B., and Davie, E. 'Operating and Financial Review-views of analysts and institutions investors', ICAS, Edinburgh, 1994.

Everyone would like to be the best, but most organizations lack the discipline to figure out with egoless clarity what they can be the best at and the will to do whatever it takes to turn that potential into reality. They lack the discipline to rinse cottage cheese. Jim Collins 